\title{
Penyidikan Anak Pelaku Tindak Pidana Dalam Perspektif Undang-Undang No 35 Tahun 2014
}

\author{
Wahab Aznul Hidaya \\ Ilmu Hukum, Universitas Muhammadiyah Sorong \\ Email : Wahabaznulhidaya@um-sorong.ac.id
}

\begin{abstract}
The development of human civilization, which started from an agrarian society towards an industrial society, has had a significant impact on the life of the socio-cultural values at most levels of society. It is also inseparable from the criminal acts committed by adults and it is not uncommon for these crimes to be committed by minors, factors that cause them to commit these crimes due to inadequate economic factors from their parents, environmental factors where the child lives, the lack of supervision from the parents or the lack of moral education that the child gets, so that he tends to take deviant actions. This research is empirical normative research. (1) The implementation of the investigation of criminal acts committed by children at the Sorong City Police is carried out with the initial step of conducting an investigation, enforcement, examination, completion and submission of case files. In the event that the investigator has carried out the task of investigating, the investigator is obliged to notify the public prosecutor with a notification letter of the commencement of the investigation accompanied by an official report. (2) Obstacles in carrying out investigations faced by the Sorong City Police. (a) Internal factors, Basically the police do not have many difficulties both in making arrests and in carrying out investigations, because generally the children are not really aware of what they are doing and the consequences that result from their actions. (b) External Factors, External barriers that are commonly encountered by investigators are in giving understanding to the parent / guardian, or family of the child who committed the crime.
\end{abstract} Keywords : Child Investigation, Child Crime, Law Number 35 of 2014.

\begin{abstract}
Abstrak
Perkembangan peradaban manusia yang berawal dari masyarakat agraris menuju masyarakat industrial telah membawa dampak signifikan terhadap kehidupan tata nilai sosiokultural pada sebagian besar lapisan masyarakat. Melihat dari jumlah penduduk yang ada di Kota Sorong sudah mencapai 481.890, tidak terlepas juga dari yang namanya tindak kriminalitas yang dilakukan oleh orang dewasa dan tidak jarang tindak kriminalitas ini dilakukan oleh anak yang masih dibawah umur, faktor yang menyebabkan mereka melakukan tindakan kriminalitas tersebut karena faktor ekonomi yang kurang memadai dari orang tua, faktor lingkungan tempat anak tersebut tinggal, pengawasan yang kurang dari orang tua ataupun minimnya pendidikan akhlak yang di dapat anak tersebut sehingga cenderung melakukan tindakan yang menyimpang. Penelitian ini adalah penelitian normatif empiris. (1) Pelaksanaan Penyidikan Terhadap Tindak Pidana Yang Dilakukan Oleh Anak Di Polres Sorong Kota dilakukan dengan langkah awal melakukan penyelidikan, penindakan, pemeriksaan, penyelesaian dan penyerahan berkas perkara. Dalam hal penyidik telah
\end{abstract}


melakukan tugas penyidikan maka penyidik wajib memberitahukan kepada penuntut umum dengan surat pemberitahuan dimulainya penyidikan yang dilampiri dengan berita acara. (2) Hambatan-hambatan dalam melakukan penyidikan yang dihadapi oleh Polres Sorong Kota. (a) Faktor Internal, Pada dasarnya pihak kepolisian tidak banyak kesulitan baik di dalam melakukan penangkapan maupun dalam melakukan peyidikan, karena umumnya anak-anak itu tidak begitu menyadari dengan apa yang dilakukannya dan akibat yang ditimbulkan oleh perbuatannya. (b) Faktor Eksternal, Hambatan secara ekstern yang biasa ditemui oleh penyidik adalah dalam memberikan pengertian terhadap orang tua/wali, atau keluarga dari anak yang melakukan tindak pidana.

Kata Kunci : Penyidikan Anak, Tindak Pidana Anak, Undang-Undang Nomor 35 Tahun 2014

\section{PENDAHULUAN}

Masalah perilaku delinkuensi anak kini semakin menggejalah dimasyarakat, baik di negara maju maupun negara yang sedang berkembang. Perkembangan peradaban manusia yang berawal dari masyarakat agraris menuju masyarakat industrial telah membawa dampak signifikan terhadap kehidupan tata nilai sosiokultural pada sebagian besar lapisan masyarakat. Nilai-nilai yang bersumber dari kehidupan industrial revolusi teknologi semakin menggeser nilai-nilai kehidupan agraris dan proses tersebut terjadi secara berkesinambungan sehingga pada akhirnya membawa perubahan dalam tata nilai termasuk pola-pola perilaku dan hubungan masyarakat.

Melihat dari jumlah penduduk yang ada di Kota Sorong sudah mencapai 481.890, tidak terlepas juga dari yang namanya tindak kriminalitas yang dilakukan oleh orang dewasa dan tidak jarang tindak kriminalitas ini dilakukan oleh anak yang masih dibawah umur, faktor yang menyebabkan mereka melakukan tindakan kriminalitas tersebut karena faktor ekonomi yang kurang memadai dari orang tua, faktor lingkungan tempat anak tersebut tinggal, pengawasan yang kurang dari orang tua ataupun minimnya pendidikan akhlak yang di dapat anak tersebut sehingga cenderung melakukan tindakan yang menyimpang. Tindakan kriminalitas yang dilakukan oleh anak begitu beragam mulai dari kasus pengeroyokan, pengerusakan, penganiayaan ringan maupun berat, sampai dengan kasus pencurian tersebut biasanya pencurian biasa, pencurian ringan dan curanmor.

\section{Tabel 1}

Jumlah Kasus Tindak Pidana Pelaku Anak Di Kota Sorong 2015-2019

\begin{tabular}{llcccccc}
\hline No. Jenis Kejahatan & \multicolumn{5}{c}{ Tahun } \\
\cline { 3 - 7 } & \multirow{2}{*}{} & 2015 & 2016 & 2017 & 2018 & 2019 \\
\hline 1 & Pencurian & 2 & 7 & 8 & 5 & 6 \\
\hline
\end{tabular}




\begin{tabular}{clccccc}
\hline 2 & Pencurian dengan kekerasaan & 10 & 7 & 5 & 8 & 10 \\
\hline 3 & Pencurian dengan pemberatan & 4 & 7 & 5 & 5 & 10 \\
\hline 4 & Curanmor & 5 & 10 & 11 & 12 & 15 \\
\hline \multirow{2}{*}{ Jumlah } & 21 & 31 & 29 & 30 & 41 \\
\hline
\end{tabular}

Penulisan ini membahas suatu permasalahan yang berhubungan dengan problematika penyidikan terhadap anak sebagai pelaku tindak pidana dalam kaitannya dengan penerapan suatu proses penyidikan sesuai dengan ketentuan KUHAP dan UU perlindungan Anak Nomor 35 Tahun 2014 untuk tetap melindungi hak-hak anak sebagai generasi penerus, terlepas dari apapun bentuk tindak pidana yang dilakukan oleh anak. Berdasarkan hal tersebut di atas maka dapat dirumuskan permasalahan dalam penelitian ini sebagai berikut (1) Bagaimana pelaksanaan penyidikan terhadap tindak pidana yang dilakukan oleh anak di Polres Sorong Kota?; (2) Faktor-faktor apa yang menyebabkan terjadinya Problem penyidikan tindak pidana yang dilakukan oleh anak?; (3) Bagaimana upaya yang seharusnya dilakuan oleh Polres Sorong Kota dalam mengatasi problem penyidikan tindak pidana yang dilakukan oleh anak ?

Ahmad Eko Setiawan Arbie (2016) "Penyidikan Terhadap Anak Yang Melakukan Tindak Pidana Pencabulan". Penyidikan terhadap anak pelaku tindak pidana pencabulan sama halnya dengan penyidikan yang dilakukan terhadap anak pelaku tindak pidana lainnya. Penyidikan kasus pidana pencabulan yang dilakukan oleh anak dilakukan oleh kepolisian sesuai dengan UU No. 8 Tahun 1981 tentang Hukum Acara Pidana (KUHAP) dan UU No. 11 Tahun 2012 tentang Sistem Peradilan Pidana Anak. Penyidikan terhadap anak pelaku tindak pidana pencabulan dilakukan oleh polisi wanita dan dalam beberapa hal jika perlu dengan bantuan polisi pria.

Selamet Riadi (2016) "Peran Penyidik Polri Dalam Penerapan Diversi Terhadap Anak Yang Berkonflik Dengan Hukum”. Proses diversi pada tingkat penyidikan berdasarkan Pasal 7 ayat (1) Undang-undang No. 11 Tahun 2012 Tentang Sistem Peradilan Pidana Anak pada tingkat penyidikan wajib diupayakan diversi dalam pasal 7 ayat (2) juga disebutkan mengenai syarat diversi adalah tindak pidana yang dilakukan anak tersebut diancam dengan pidana penjara kurang dari 7 (tujuh) tahun dan bukan merupakan Pengulangan tindak pidana. Pada pasal 8 ayat (1) Undang-undang No. 11 tahun 2012 dijelaskan dalam proses diversi pada tingkat penyidikan dilakukan melalui musyawarah dengan melibatkan orang tua/wali anak, Pembimbing Kemasyarakatan dan Pekerja Sosial dengan mengedepankan pendekatan Restorative Justice. 
Gusti Agus Adhi Bhayangkara, Ni Putu Rai Yuliartini, Ratna Artha Windari (2018) "Perlindungan Hukum Terhadap Anak Sebagai Pelaku Tindak Pidana Pencurian". Faktor anak melakukan tindak pidana pencurian di Kabupaten Buleleng karena adanya pengaruh ekternal yang menjadi penyebab anak melakukan tindak pidana pencurian. Banyaknya kasus pencurian yang terjadi disebebkan oleh beberapa faktor. Adapun faktor-faktor yang menjadi penyebab anak melakukan tindak pidana pencurian di Kabupten Buleleng yaitu: 1) Faktor Ekonomi, 2) Faktor keluarga, 3) Faktor Lingkungan, 4) Faktor Pendidikan, dan 5) Faktor kurangnya sosialisasi terkait tentang hukum.

Febrina Annisa (2016) "Penegakkan Hukum Terhadap Anak Yang Melakukan Tindak Pidana Pencabulan Dalam Konsep Restorative Justice". Tindak pidana pencabulan yang dilakukan oleh anak merupakan masalah yang sangat kompleks dibandingkan dengan tindak pidana yang dilakukan oleh orang dewasa. Hal ini dikarenakan Anak adalah calon penerus generasi bangsa. Jika sejak kecil mereka telah direcoki oleh hal-hal yang merusak mental mereka, maka akan menjadi apa mereka saat dewasa nanti.

Yutirsa Yunus (2013) “Analisa Konsep Restorative Justice Melalui Sistem Diversi dalam Sistem Peradilan Pidana Anak di Indonesia". Konsep baru dalam UU SPPA ini dipandang baik utamanya konsep diversi yang menghindarkan anak dari jalur litigasi, dengan beberapa lembaga baru yang dibuat tentunya UU SPPA ini diharapkan konsep restorative justice dapat terlaksana secara efektif.

\section{METODE PENELITIAN}

Metode Penelitian yang peneliti gunakan adalah penelitian normatif empiris. Penelitian hukum normatif yaitu penelitian hukum yang mengkaji hukum tertulis dari aspek teori, sejarah, filosofi, perbandingan, stuktur dan komposisi, lingkup dan materi, penjelasan umum dari pasal demi pasal, formalitas dan kekuatan mengikat suatu undang-undang tetapi tidak mengikat aspek terapan atau implementasinya. Penelitian empiris adalah penelitian hukum positif tidak tertulis mengenai perilaku anggota masyarakat dalam hubungan hidup bermasyarakat.

\section{PEMBAHASAN}

\section{Penyidikan Tindak Pidana Yang Dilakukan Oleh Anak Di Polres Sorong Kota}

Sesuai dengan Pasal 1 point 13 Undang-Undang Nomor 2 Tahun 2002 tentang Kepolisian Negara Republik Indonesia, menjelaskan bahwa penyidikan adalah serangkaian tindakan penyidik dalam hal menurut cara yang diatur dalam Undang-Undang untuk mencari serta mengumpulkan bukti yang dengan bukti itu membuat terang suatu tindak pidana yang terjadi guna menemukan tersangkanya. 
Proses penyidikan tindak pidana sebagaimana yang diatur dalam buku himpunan Buku Petunjuk Pelaksanaan, Buku Petunjuk Laporan, dan Buku Petunjuk Proses Penyidikan Tindak Pidana menyatakan bahwa penyidikan tindak pidana terdiri dari 5 (lima) tahap yakni: (1) Penyelidikan; (2) Penindakan yang meliputi pemanggilan, penangkapan, penggeledahan, penyitaan dan penahanan; (3) Pemeriksaan; (4) Pemberkasan; dan (5) Penyerahan berkas perkara ke penuntut umum.

Proses penyidikan yang dilakukan oleh Penyidik/penyidik pembantu Polri terhadap tersangka anak ada hal-hal yang menjadi kekhususan bagi anak yang tidak bisa dipandang sama terhadap pemeriksaan bagi orang dewasa. Hal ini perlu dilakukan sebagai upaya untuk melindungi dan menjamin terlaksananya hak-hak asasi manusia terhadap tersangka anak dan memberikan perlindungan hukum terhadap tersangka anak guna mendapatkan kebenaran terhadap suatu perbuatan pidana yang dilakukan oleh anak tersebut.

Dalam hal ini, perlindungan hukum yang diberikan oleh penyidik/penyidik pembantu anak dalam bentuk pemberian hak-hak yang telah ditentukan dalam Undang-Undang Nomor 35 Tahun 2014 tentang Perlindungan Anak, Undang-Undang Nomor 11 Tahun 2012 Tentang Sistem Peradilan Pidana Anak, Konvensi PBB tentang Hak-hak anak, serta peraturan Perundang-Undangan lainnya yang mendukung adanya perlindungan hukum terhadap anak yang menjadi tersangka dalam perkara pidana.

Dari hasil penyidikan yang dilakukan oleh penyidik anak Polres Sorong Kota korban telah melakukan pertemuan dan telah bersepakat untuk berdamai melalui upaya diversi, dalam pertemuan tersebut pelaku didampingi oleh ayah kandung pelaku meminta maaf sebesarbesarnya kepada korban atas perbuatan pelaku kepada korban dan korban pun telah memaafkan pelaku, dan juga menyatakan bahwa saat ini pelaku merasa menyesal dan mengakui kesalahan yang telah ia perbuat kepada korban untuk itu ia berjanji untuk tidak akan mengulanginya lagi dikemudian hari baik kepada korban maupun kepada orang lain.

Sesuai hasil penelitian menunjukkan bahwa tersangka diperiksa oleh pemeriksa bernama Bripka Hamdan pada hari Senin 1 Juni 2020 pada pukul 18.00 WIT di ruang penyidikan anak. Dalam BAP tersebut terdapat 20 (dua puluh) pertanyaan yang ditanyakan oleh pemeriksa kepada tersangka. Pada akhir pertanyaan tersangka menjelaskan bahwa tersangka tidak merasa dipaksa atau dipengaruhi selama proses pemeriksa berlangsung, maupun orang lain.

Berdasarkan hasil penelitian dan keterangan yang diberikan oleh Kanit PPA bahwa tersangka diperiksa di ruang penyidikan anak yang sesuai hasil pengamatan peneliti bahwa 
kondisi ruangan pemeriksaan dengan luas ruangan berukuran 3X8.5 meter persegi dilengkapi dengan 1 buah pendingin ruangan, 1 set TV, 5 set meja kursi untuk pemeriksaan dilengkapi dengan sarana komputer.

Dalam pelaksanaan penyidikan yang dilakukan oleh penyidik dapat dilihat bahwa dalam rangka melakukan suatu proses penyidikan ini, penyidik menggunakan fasilitas yang memadai untuk dilakukan penyidikan bagi tersangka anak pelaku tindak pidana. Dalam pelaksanaannya, pelaku dihadapkan pada suatu upaya perlindungan anak dan kesejahteraan anak dalam rangka mencari informasi yang sebaik-baiknya dengan mempertimbangkan faktor yuridis, psikologis dan kriminologis seorang anak. Berdasarkan hasil wawancara yang dilakukan oleh peneliti diperoleh informasi bahwa penyidik/penyidik pembantu di Polres Sorong Kota dalam menangani suatu tindak pidana yang pelakunya adalah anak sebagai pelaku, selalu berpedoman dengan Kitab Undang-Undang Hukum Acara Pidana dan UndangUndang Sistem Peradilan Pidana Anak, yang pada pelaksanaan proses penyidikan antara kasuskasus anak dengan kasus orang dewasa harus dibedakan perlakuannya sebagi upaya melindungi hak-hak asasi tersangka pelaku anak tersebut. Hal tersebut sesuai dengan keterangan Kanit PPA Polres Sorong Kota yang menerangkan sebagai berikut:

"Pada prinsipnya penyidikan antara kasus anak dengan kasus orang dewasa memiliki perbedaan. Hal ini ditempuh dalam rangka untuk memberikan perlindungan hak-hak asasi anak. Meskipun di Polres Sorong Kota hanya memiliki beberapa penyidik anak yang telah tersertifikasi anak, namun saya telah memberikan arahan kepada Penyidik/penyidik pembantu maupun anggota pemeriksa tentang tata cara penanganan kasus anak yang berhadap dengan hukum (ABH)”.

\section{Faktor-Faktor Yang Menyebabkan Munculnya Problematika penyidikan Tindak Pidana Anak Di Polres Sorong Kota}

Dalam suatu ketentuan dalam sistem peradilan pidana anak, peranan penegak hukum memegang peranan yang penting dalam menjaga citra hukum yang berlaku. Namun dalam hal pelaksanaan hukum sistem peradilan pidana, ternyata proses yang berlangsung adakalanya memiliki suatu pola pikir yang berbeda antara satu dengan yang lain baik itu menyangkut problematika yuridis maupun problematika praktis dalam pelaksanaan proses penyidikan terhadap anak tersangka tindak pidana.

Adapun problem praktis dan problem yuridis akan menunjukkan bahwa adanya ketimpangan dalam pelaksanaan suatu sistem. Hal ini akan dicoba untuk mengkaji mengenai:

\section{Problema yuridis}


Pada dasarnya, problematika yuridis erat kaitannya dengan adanya suatu aturan perundang-undangan yang berlaku. Tidak terkecuali dengan perundang-udangan dalam pelaksanaan penyidikan tindak pidana anak. Dengan mengacu pada Undang-Undang Sistem Peradilan Pidana Anak, bahwa penyidik merupakan penyidik Polri dan atau Penyidik Pegawai Negeri Sipil (PPNS), namun dalam kenyataannya pelaksanaan kualifikasi terhadap penyidik tindak pidana anak tidak memiliki unsur keseragaman sehingga menyebabkan adanya suatu ketimpangan (ambiguitas) dalam hal pelaksanaan penyidikan. Keambiguitasan penyidik dalam melakukan suatu tindak pidana ini dikarenakan, penyidik/penyidik pembantu anak belum sepenuhnya mengerti mengenai adanya pedoman penyidikan anak pelaku tindak pidana.

Adapun dalam penyidikan anak juga terdapat problematika praktis yang dipengaruhi oleh adanya beberapa faktor yang mempengaruhi tindakan dan perilaku penyidik/penyidik pembantu dalam proses penyidikan tindak pidana anak di Polres Sorong Kota. Akibat dari tindakan dan perilaku peyidik/penyidik pembantu anak yang menyimpang dalam melaksanakan penyidikan anak sebagai pelaku tindak pidana, dengan demikian akan mempengaruhi penegakan hukum itu sendiri.

Dari hasil penelitian yang dilakukan oleh peneliti di Polres Sorong Kota dapat dijelaskan tentang adanya beberapa faktor yang mempengaruhi penyidikan yang dilakukan oleh penyidik/penyidik pembantu anak dalam proses penyidikan anak, yaitu:

\section{Faktor penegak hukum;}

Faktor penegak hukum sangat mempengaruhi tindakan dan perilaku penyidik/penyidik pembantu dalam penyidikan tindak pidana dimana anak sebagai pelaku tindak pidana. Masyarakat sering mengeluh atas kinerja Polri dalam penanganan tindak pidana pada umumnya dengan berbagai alasan, antara lain terlalu lambat/santai, tidak proaktif dalam menangani laporan yang dilaporkan masyarakat hingga kepada kualitas personil Polri yang tidak baik dalam menangani perkara yang dilaporkan.

Berdasarkan pada hasil penelitian bahwa kualitas atau kemampuan Polri yang diharapkan oleh masyarakat adalah terselenggaranya profesional, efektif, efisien dan modern yang dapat diuraikan sebagai berikut: (1) Profesional "Wujud dari profesional yaitu pelaksanaan tugas yang didasari oleh etika profesi sehingga terselenggara secara tertib, ilmiah dan santun"; (2) Efektif "Kemampuan melaksanakan tugas dan mencapai sasaran yang dipilih secara tepat dalam waktu yang singkat dan energi (daya dan dana yang sekecil-keilnya (hemat dan sukses)"; (3) Efisien "Kemampuan melaksanakan tugas dengan benar dan terselesikannya 
sesuai dengan ketentuan yang ada seperti yang diinginkan"; (4) Modern "Berpikir maju, strategis dan atau mencapai hasil dengan bantuan berbagai peralatan/teknologi mutakhir sehingga semua terselesaikan secara efekti, efisien dan profesional”.

Dari hasil penelitian dan pengamatantindakan dan perilaku penyidik atau penyidik pembantu dalam pelaksanaan penyidikan tindak pidana anak di Polres Sorong Kota dapat dijelaskan bahwa dengan melihat kemampuan dan cara kerja penyidik/penyidik pembantu anak dalam setiap proses penyidikan tindak pidana anak bila dikaitkan dengan pendidikan yang beraneka ragam mereka peroleh serta dengan sarana, prasarana dan dana yang minimal, ditambah lagi dengan tidak dapat terpenuhinya persyaratan sebagai penyidik anak, maka penyidikan tindak pidana anak sebagaimana diharapkan masyarakat untuk bertindak profesional efektif, efisien, professional dan modern belum dapat diwujudkan oleh penyidik/penyidik pembantu anak. Penyidik/penyidik pembantu anak yang melakukan penyidikan tindak pidana anak maupun ketentuan perundang-undangan mengenai anak. Karena sampai saat ini belum pernah ada pendidikan kejuruan dibidang anak maupun pemberian pengetahuan hukum acara pidana anak sebagaimana yang dimaksud dalam UndangUndang Nomor 11 Tahun 2012 Tentang Sistem Peradilan Pidana Anak. Pendidikan kejuruan yang diberikan kepada penyidik/ penyidik pembantu khususnya dibidang anak diharapkan dapat diterapkan oleh penyidik anak dalam melakukan penyidikan anak secara baik dan benar tanpa ada lagi pelanggaran terhadap anak. Dengan demikian, pendidikan kejuruan khusus anak diharapkan dapat meningkatkan kemampuan penyidik/penyidik pembantu terhadap tersangka anak dalam melaksanakan penyidikan tindak pidana anak.

\section{Upaya Yang Seharusnya Dilakukan Polres Sorong Kota Dalam Mengatasi Problem Penyidikan Tindak Pidana Yang Dilakukan Oleh Anak}

Sesuai dengan undang-undang Nomor 2 Tahun 2002 tentang Kepolisian Negara Republik Indonesia, Polri dalam mengemban tugasnya wajib memberikan perlindungan dan pelayanan kepada masyarakat dengan sebaik-baiknya, khususnya terhadap perempuan dan anak yang berhadapan degan hukum. Seringkali kita melihat bahwa kenyataan masih banyak anggota Polri yang belum memahami tentang hak asasi anak terutama yang bertugas pada sektor pelayanan masyarakat sehingga perlu diadakan program-program pelatihan tentang pemahaman hak-hak anak dan perlindungan anak, peradilan anak, perspektif gender, sensitifitas terhadap anak dan kebijakan Polri tentang penanganan anak. Berdasarkan pada kenyataan tersebut dimasa yang akan datang hendaknya di lingkungan kerja Polres Sorong Kota diharapkan mampu untuk: 


\section{Memahami ruang lingkup tugas dan kewenangan Polri tentang Perlindungan Anak}

Dalam rangka pemahaman ruang lingkup tugas dan kewenangan penyidik/penyidik pembantu tentang perlindungan anak hendaknya wajib dilaksanakan untuk dimasa yang akan datang dengan melakukan suatu terobosan-terobosan yang diharapkan dapat menjamin suatu perspektif anak tidak hanya sebagai pelaku tindak pidana melainkan perspektif anak ditinjau dari sudut pandang anak sebagai korban. Dan pandangan anak ditinjau dari sudut pandang kemasyarakatan.

Adanya sudut pandang yang dimiliki oleh penyidik/penyidik pembantu ini diharapkan akan tercipta suatu keadilan restoratif. Keadilan restoratif ini dilakukan dalam rangka untuk menghindarkan suatu stigmatisasi dari anak yang berhadapan dengan hukum merupakan suatu anak nakal yang wajib untuk dimintakan pertanggungjawabkan perbuatannya dalam suatu peradilan dan harus menjalankan sanksinya di dalam suatu penjara.

Dengan memiliki pemikiran akan pentingnya keadilan restoratif diharapkan semua aparat penegak hukum terutama penyidik/penyidik pembantu tindak pidana anak dapat menghindarkan suatu proses penyidikan yang menggunakan kekerasan terhadap anak dan atau melakukan tindakan manuver yang membahayakan anak baik dari segi mental, fisik maupun psikologis anak. Penyidik/penyidik pembantu anak harus mampu untuk memahami bahwa dalam suatu proses penyidikan anak ini nanti dimasa yang akan datang tidak hanya diupayakan sebagai upaya pertanggungjawaban pidana namun lebih daripada itu, dalam taraf penyidikan anak, anak yang berhadapan dengan hukum memiliki suatu tanggungjawab moral yang harus diperbaiki sehingga anak tersebut tidak mengulangi perbuatan yang sama untuk kedua kalinya.

Pemahaman seperti ini tentunya sejalan dengan kewajiban Polri dalam PP Nomor 2 Tahun 2002 Pasal 4 yang menyatakan bahwa kewajiban polri mencakup: (1) Memberikan perlindungan, pengayoman dan pelayanan sebaik-baiknya kepada masyarakat; (2) Memperhatikan dan menyelesaikan dengan sebaik-baiknya laporan dan atau pengaduan masyarakat.

Berbicara tentang penanggulangan kejahatan pada umumnya dan delinkuensi anak pada khususnya., tidak dapat dilepaskan pada pembicaraan mengenai Kebijakan Kriminal (criminal policy) sebagai usaha rasional masyarakat untuk menanggulangi kejahatan, di dalam gerak operasionalnya yang terarah pada dua jalur, yaitu : (a) Kebijakan Kriminal Jalur Penal; dan (b) Kebijakan Kriminal Jalur Non penal. 
Secara kasar, dapat dibedakan, bahwa upaya penanggulangan kejahatan jalur penal lebih menitik beratkan pada sifat "represif" (penumpasan/pemberantasan/penindasan) setelah kejahatan terjadi, sedangkan upaya penanggulangan kejahatan jalur non-penal, lebih menitik beratkan pada sifat "preventif" (pencegahan/penangkalan/pengendalian) sebelum kejahatan terjadi dikatakan pembedaan secara kasar, karena pada hakikatnya, tindakan represif juga dapat dilihat sebagai tindakan preventif dalam arti luas dengan mempertimbangkan : (a) Keterbatasan penggunaan jalur penal dalam penanggulangan delinkuensi anak, lebih mencerminkan sifatnya sebagai kurieren amsymptom (pengobatan simptomatik) dari pada "pengobatan kausatif"; (b) Hasil pengamatan praktek-praktek pendekatan justisial konvensional cenderung merugikan masa depan anak, stigmatisasi anak (stigmatisasi anak secara kriminologi merupakan faktor kriminogen); dan (c) Semakin gencarnya tuntutan masyarakat internasional akan perlunya perlindungan hak-hak anak (termasuk hak-hak anak pelaku delinkuensi), antara lain tampak dari Resolusi PBB yaitu : (1) Convention of the Rights of the Child (CRC) ditetapkan berlaku di Indonesia dengan Keppres No. 36 Tahun 1990; (2) UN Standard Minimum Rules for the Administration of Juvenile Justice (The Beijing Rule); (3) UN Standard of the Protection of Juvenile De-prived of their Liberty; dan (4) The Tokyo Rule, maka cukup beralasan apabila dinyatakan bahwa upaya penanggulangan delinkuensi anak, harus diusahakan dengan cara-cara yang lebih mengedepankan 'kepentingan anak" (nie oesrinterest of the child), tanpa kehilangan maknanya sebagai upaya pengendalian terhadap terjadinya gejala tersebut di masyarakat.

\section{SIMPULAN}

Pelaksanaan Penyidikan Terhadap Tindak Pidana Yang Dilakukan Oleh Anak Di Polres Sorong Kota dilakukan dengan langkah awal melakukan penyelidikan, penindakan, pemeriksaan, penyelesaian dan penyerahan berkas perkara. Dalam hal penyidik telah melakukan tugas penyidikan maka penyidik wajib memberitahukan kepada penuntut umum dengan surat pemberitahuan dimulainya penyidikan yang dilampiri dengan berita acara. Setelah semua selesai diperiksa oleh penyidik maka dilakukan pemberkasan perkara atau berkas perkara, yang kemudian berkas perkara tersebut diserahkan ke kejaksaan dimana terjadinya tindak Pidana / locus delicty, apabila sudah benar kemudian diberi stempel POLRI dan apabila belum lengkap maka akan dikembalikan untuk diperbaiki.

Hambatan-hambatan dalam melakukan penyidikan yang dihadapi oleh Polres Sorong Kota dalam mengatasi tindak pidana anak, umumnya muncul karena didorong oleh faktor-faktor sebagai berikut : (a) Faktor Internal; (2) Faktor Eksternal 
Upaya Polres Sorong Kota Dalam Mengatasi Hambatan Dalam Penyidikan Tindak Pidana Anak dilakukan dengan cara-cara antara lain: (a) Memahami ruang lingkup tugas dan kewenangan POLRI tentang Perlindungan anak; (b) Pemahaman mengenai diversi dan diskresi POLRI dalam sistem peradilan anak; (c) Mampu untuk menterjemahkan dan membahas prosedur yang dilakukan dalam menangani anak yang berhadapan dengan hukum.

\section{DAFTAR PUSTAKA}

\section{Buku}

Ahmad Eko Setiawan Arbie. 2016. Penyidikan Terhadap Anak Yang Melakukan Tindak Pidana Pencabulan. Lex Crimen. Vol. V/No. 3. 89-96.

Selamet Riadi. 2016. Peran Penyidik Polri Dalam Penerapan Diversi Terhadap Anak Yang Berkonflik Dengan Hukum (Studi Di PPA Polres Lombok Barat). Jurnal Ius. Vol Iv| Nomor 2. 124-136.

Gusti Agus Adhi Bhayangkara, Ni Putu Rai Yuliartini, Ratna Artha Windari. 2018. Perlindungan Hukum Terhadap Anak Sebagai Pelaku Tindak Pidana Pencurian (Studi Kasus Di Polres Buleleng). E-Journal Komunitas Yustisia. Volume 1 No. 2. 1-11.

Febrina Annisa. 2016. Penegakkan Hukum Terhadap Anak Yang Melakukan Tindak Pidana Pencabulan Dalam Konsep Restorative Justice. Adil: Jurnal Hukum.Vol. 7 No.2. 202211.

Yutirsa Yunus. 2013. Analisa Konsep Restorative Justice Melalui Sistem Diversi dalam Sistem Peradilan Pidana Anak di Indonesia. Jurnal Rechtsvinding. Volume 2 No 2

Hadjon, Philipus M, Perlindungan Hukum Bagi Rakyat di Indonesia, Bina Ilmu, Surabaya, 1997.

Kusuma, Mulyana W, Hukum dan Hak-Hak Anak, CV. Rajawali, Jakarta, 1986

M. Nasir, 2013. Anak Bukan Untuk Dihukum, Sinar Grafika, Jakarta.

\section{Perundang-Undang}

Undang-Undang Nomor 8 Tahun 1981 Tentang Hukum Acara Pidana (KUHAP).

Undang-Undang Nomor 2 Tahun 2002 Tentang Kepolisian Republik Indonesia. 
Undang-Undang Nomor 11 Tahun 2012 Tentang Sistem Peradilan Pidana Anak.

Undang-Undang Nomor 35 Tahun 2014 Tentang Perlindungan Anak.

Perkap Nomor 6 Tahun 2019 Tentang Penyidikan Tindak Pidana. 